\title{
MOBILE ATM USING ANDROID APPLICATION
}

\author{
Rashmi Tupe \\ Department of CSE \\ PREC, Loni, Maharashtra, India \\ Aarti Pagare \\ Department of CSE \\ PREC, Loni, Maharashtra, India
}

\author{
Sophia Salve \\ Department of CSE \\ PREC, Loni, Maharashtra, India \\ Pooja Dushing \\ Department of CSE \\ PREC, Loni, Maharashtra, India
}

\author{
Dr. Vaishali Vikhe \\ Department of CSE \\ PREC, Loni, Maharashtra, India
}

\begin{abstract}
Nowadays, dependency on banking in the virtual world has been increased to the peak position. To make it consistent advanced technologies should be used. As OTP is currently used worldwide for security purposes, it can be overruled by $Q R$ code. Main advantage of $Q R$ code over OTP data storage. OTP can only confirm that the user is authorized user and not some third party is involved in this transaction while $Q R$ code not only confirms the authorized user but $Q R$ code itself can store information such as transaction id, transaction date, time and also amount of transaction. So, there is no need of explicitly keeping track of transaction every transaction. Aim of this paper to enhance the functionality of ATM machine using android application. Proposed system is combining the ATM and mobile banking and minimizes the time of withdrawing cash from ATM. This will increase the speed of transaction almost three times fast; could have excellent impact on customer's satisfaction. With the help of QR code information get encrypted so it also increases security. As the population increasing ATM queues will be longer day by day. By implementing proposed system current system will not hampered, by doing some minor changes in existing system it will be possible to get cash within seconds. According to analyst report, cost of transaction using mobile application i almost ten times less than ATM and about fifty times less, if physical bank branch used.
\end{abstract}

Keywords- Blockchain, Hashing Function, AES, Mobile Computing, Cloud Com-puting, Withdrawal, ATM, QR Code

\section{INTRODUCTION}

In previous decades, to withdraw the money, we have to visit nearest banks, standing for our turn in long queue, fill form with our credentials to give particulars/bank worker; only then we get the money. it was like a big task to withdrawal cash from our banking account and also we have to wait for a lot of time. also customer needs to be present physically. there were many security issues. after some period, technology gear up and some great developers invented cash vending machine called atm machine, which gives cash from specific banking account using a debit card. then banks started to install atm machines, which gives you money from your banking account within few minutes without filling any form like previous bank era. you can find atm machine everywhere. but still sometimes, you have to wait in the long queue in front of atm machine. customers are mostly using their smart cards while shopping or other transaction. but still there is need of physical cash at some places, for those consumers have to visit nearest atm to get cash from his banking account. nowadays, large numbers of atm machines are available worldwide. in 2016, about $34000 \mathrm{~atm}$ machines are available only in india. but because of increasing population which leads to increased users, still sometimes, we have to wait in a queue in front of the atm machines. sometimes, customers are in hurry, but to withdraw cash from atm. customer have to wait long queue by doing nothing. not only this, inside atm also customer have choose many unwanted options repeatedly. customers have to choose his language, type of account every time which is very hectic and time consuming process. can't we do something to save our time to withdrawal the cash by doing some modification in existing atm system, while standing in the outside waiting queue or on the way to atm machine? yes we can, by using this proposed system. 'efficient cash withdrawal using qr code technology.' nowadays use of mobile applications are increasing; people are very habitual to use mobile app.

\section{Proposed Algorithm}

\section{A. SHA-256 Algorithm -}

This algorithm will be used to convert data in a block of block chain. The SHA-256 (Secure Hash Algorithm 256) is a cryptographic hash functions designed by the United States 


\section{International Journal of Engineering Applied Sciences and Technology, 2021 \\ Vol. 6, Issue 3, ISSN No. 2455-2143, Pages 132-140 \\ Published Online July 2021 in IJEAST (http://www.ijeast.com)}

National Security Agency (NSA). It was first published in 2001. It uses one way compression function using a specialized block cipher and built us-ing Davies-Meyer structure. Hash functions creates small, fixed-length bit strings called message digests using arbitrary large bit strings called messages. The mes-sage digests identify the messages that produced them with a very high probability. Message Digests are like sense fingerprints that allow identification of their message, with a very low probability that different messages will share the same message di-gests. In SHA-256, messages up to 264 are transformed into message digests of size 256 bits (32 bytes). For e.g., this means that an object very large in size if passed to SHA-256 would produce a chunk of data the size of a 32-letter string of ASCII characters and not more, and that string would the object's very special fingerprint. A very basic use case of hashing is data integrity verification of large files, which actually relies on the comparison of actual and expected message digests after the transformation.

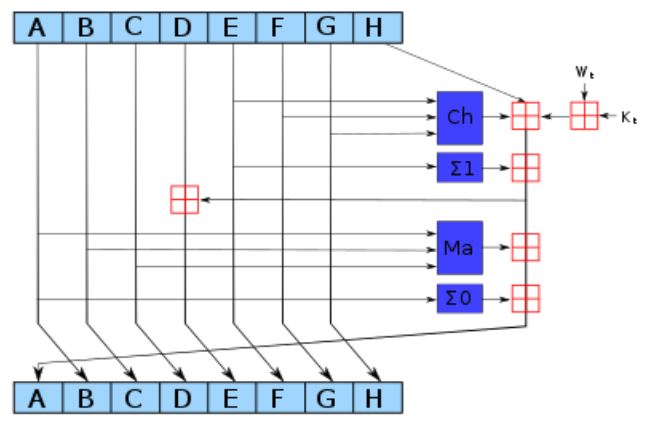

Fig. 1. Sha-256 Algorithm

\section{Input}

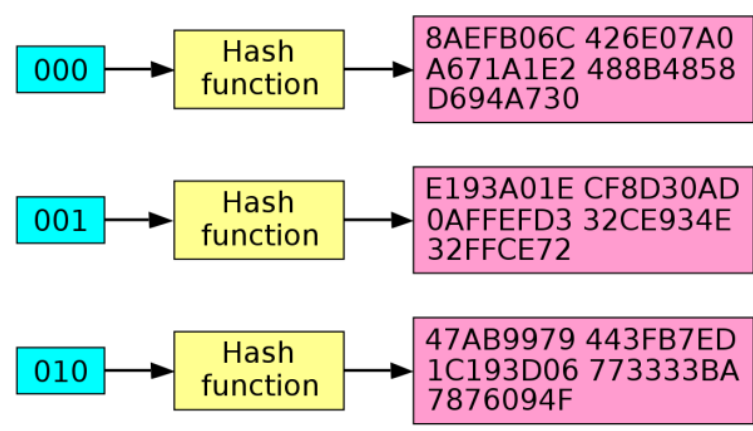

Fig. 2. Sha-256 Algorithm
The MD5 message-digest algorithm is a widely used hash function producing a 128-bit hash value. Although MD5 was initially designed to be used as a cryptographic hash function, it has been found to suffer from extensive vulnerabilities. It can still be used as a checksum to verify data integrity, but only against unintentional corruption. It remains suitable for other non-cryptographic purposes, for example for determining the partition for a particular key in a partitioned database.

MD5 was designed by Ronald Rivets in 1991 to replace an earlier hash function MD4, and was specified in 1992 as RFC 1321.

One basic requirement of any cryptographic hash function is that it should be computationally infeasible to find two distinct messages that hash to the same value. MD5 fails this requirement catastrophically; such collisions can be found in seconds on an ordinary home computer.

The weaknesses of MD5 have been exploited in the field, most infamously by the Flame malware in 2012.

On 31 December 2008, the CMU Software Engineering Institute concluded that MD5 was essentially "cryptographically broken and unsuitable for further use".

Message Digest is used to ensure the integrity of a message transmitted over an insecure channel (where the content of the message can be changed). The message is passed through a Cryptographic hash function. This function creates a compressed image of the message called Digest.

Lets assume, Alice sent a message and digest pair to Bob. To check the integrity of the message Bob runs the cryptographic hash function on the received message and gets a new digest. Now, Bob will compare the new digest and the digest sent by Alice. If, both are same then Bob is sure that the original message is not changed.

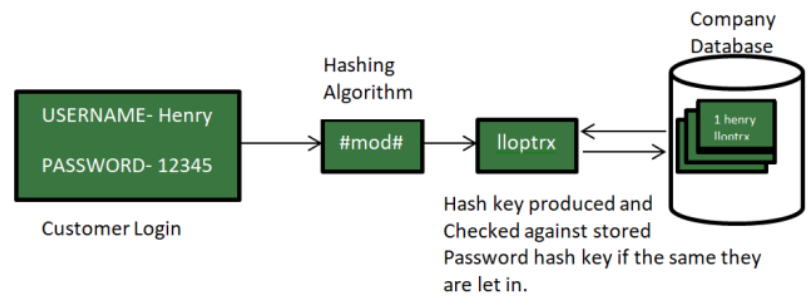

Fig. 3. Message Digest algorithm Block Diagram

\section{EXPERIMENT AND RESULT}

Test cases : 
International Journal of Engineering Applied Sciences and Technology, 2021

Vol. 6, Issue 3, ISSN No. 2455-2143, Pages 132-140

Published Online July 2021 in IJEAST (http://www.ijeast.com)

\begin{tabular}{|c|c|c|c|c|c|c|c|}
\hline $\begin{array}{l}\text { Tes } \\
\text { t Case } \\
\text { Id }\end{array}$ & $\begin{array}{l}\text { Test Case } \\
\text { Details }\end{array}$ & $\begin{array}{c}\text { Pre- } \\
\text { Requisite }\end{array}$ & Steps & Input & $\begin{array}{l}\text { Expected } \\
\text { Result }\end{array}$ & $\begin{array}{l}\text { Actual } \\
\text { Result }\end{array}$ & Result \\
\hline 1 & \begin{tabular}{l}
\multicolumn{1}{c}{ Check } \\
whether logo is \\
displayed
\end{tabular} & $\begin{array}{l}\text { Logo should } \\
\text { be displayed }\end{array}$ & $\begin{array}{l}\text { Click on } \\
\text { the } \\
\text { installed }\end{array}$ & click & $\begin{array}{l}\text { Logo should } \\
\text { be displayed }\end{array}$ & $\begin{array}{r}\text { Logo } \\
\text { displayed }\end{array}$ & Pass \\
\hline 2 & $\begin{array}{l}\text { Check the } \\
\text { textfeild }\end{array}$ & $\begin{array}{c}\text { Textfeild } \\
\text { should take value }\end{array}$ & $\begin{array}{l}\text { 1.Open the } \\
\text { app. } \\
\quad \text { 2.enter } \\
\text { value in } \\
\text { textfeild }\end{array}$ & $\begin{array}{l}\text { Enter } \\
\text { value }\end{array}$ & $\begin{array}{c}\text { Textfeild } \\
\text { should take value }\end{array}$ & $\begin{array}{c}\text { Textfeild } \\
\text { took the value }\end{array}$ & pass \\
\hline 3 & $\begin{array}{l}\text { Check the } \\
\text { register button }\end{array}$ & $\begin{array}{l}\text { On clicking } \\
\text { the register here, } \\
\text { register page } \\
\text { should be opened }\end{array}$ & $\begin{array}{l}\text { 1.open app } \\
2 . \text { click on } \\
\text { the register here } \\
\text { button }\end{array}$ & click & $\begin{array}{l}\text { On clicking } \\
\text { the register here, } \\
\text { register page } \\
\text { should be opened }\end{array}$ & $\begin{array}{l}\text { On clicking } \\
\text { the register here, } \\
\text { register page } \\
\text { opened }\end{array}$ & Pass \\
\hline 4 & $\begin{array}{l}\text { Check the } \\
\text { submit button }\end{array}$ & $\begin{array}{l}\text { On clicking } \\
\text { the submit button } \\
\text { verify otp page } \\
\text { should be opend }\end{array}$ & $\begin{array}{l}\text { 1.open app } \\
\text { 2.enter } \\
\text { details } \\
\text { 3.click } \\
\text { submit }\end{array}$ & $\begin{array}{l}\text { Click } \\
\text { submit }\end{array}$ & $\begin{array}{l}\text { On clicking } \\
\text { the submit button } \\
\text { verify otp page } \\
\text { should be opend }\end{array}$ & $\begin{array}{l}\text { On clicking } \\
\text { the submit button } \\
\text { verify otp page } \\
\text { opend }\end{array}$ & Pass \\
\hline 5 & $\begin{array}{l}\text { Check the } \\
\text { withdraw cash } \\
\text { button }\end{array}$ & $\begin{array}{l}\text { On clicking } \\
\text { withdraw cash } \\
\text { the details page } \\
\text { should be opened }\end{array}$ & $\begin{array}{l}\text { 1.open app } \\
\text { 2.login } \\
\text { 3.withdraw } \\
\text { cash }\end{array}$ & $\begin{array}{l}\text { Click } \\
\text { withdraw } \\
\text { cash }\end{array}$ & $\begin{array}{l}\text { On clicking } \\
\text { withdraw cash } \\
\text { the details page } \\
\text { should be opened }\end{array}$ & $\begin{array}{l}\text { On clicking } \\
\text { withdraw } \\
\text { the details page } \\
\text { opened }\end{array}$ & Pass \\
\hline 6 & $\begin{array}{l}\text { Check the } \\
\text { scanner }\end{array}$ & \begin{tabular}{lr}
\multicolumn{1}{c}{ On } & opening \\
the atm & scanner \\
should & open \\
phones & back \\
camera &
\end{tabular} & $\begin{array}{l}\text { 1.open atm } \\
\text { 2.click scan }\end{array}$ & $\begin{array}{l}\text { Click } \\
\text { scan }\end{array}$ & \begin{tabular}{lr}
\multicolumn{1}{c}{ On } & opening \\
the atm & scanner \\
should & open \\
phones & back \\
camera &
\end{tabular} & $\begin{array}{l}\text { On opening } \\
\text { the atm scanner } \\
\text { opened phones } \\
\text { back camera }\end{array}$ & Pass \\
\hline 7 & $\begin{array}{l}\text { Check the } \\
\text { verify button }\end{array}$ & \begin{tabular}{lr}
\multicolumn{1}{c}{ The } & verify \\
button & should \\
accept & only \\
numerical values
\end{tabular} & $\begin{array}{l}\text { 1.open app } \\
\text { 2.login } \\
\text { 3.enter otp } \\
\text { 4.click verify }\end{array}$ & $\begin{array}{l}\text { Click } \\
\text { verify }\end{array}$ & \begin{tabular}{lr}
\multicolumn{1}{c}{ The } & verify \\
button & should \\
accept & only \\
numerical values
\end{tabular} & $\begin{array}{l}\text { The verify } \\
\text { button accepted } \\
\text { only numerical } \\
\text { values }\end{array}$ & Pass \\
\hline
\end{tabular}


Screenshots:-

1. Android App Logo Screen:-
2. Registration Screen:-

\section{0:53}

\section{ATMApp}

\section{REGISTRATION}

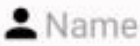

6hone

B Account Number

A Address

$\square$ Email-Address

Password

- IFSC Number

E--ATM

\section{SUBMIT}

Figure 1: App Logo

Figure 2:Registration

This is an App logo screen which will show up first after opening ATM app.
This is registration screen in which customer with bank account have to register the account . 
3 .Login Screen:-

\section{ATMApp}

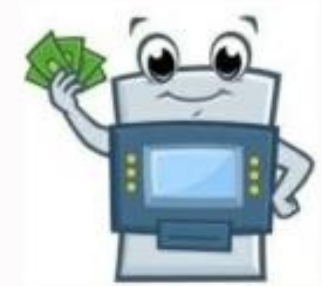

\section{Login}

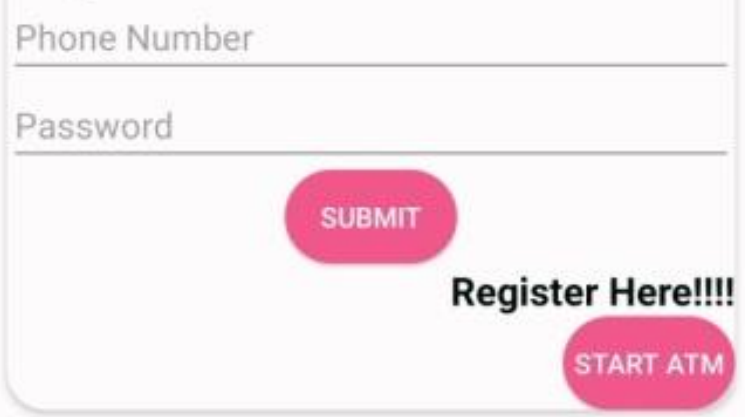

4.Withdraw Cash Button:-

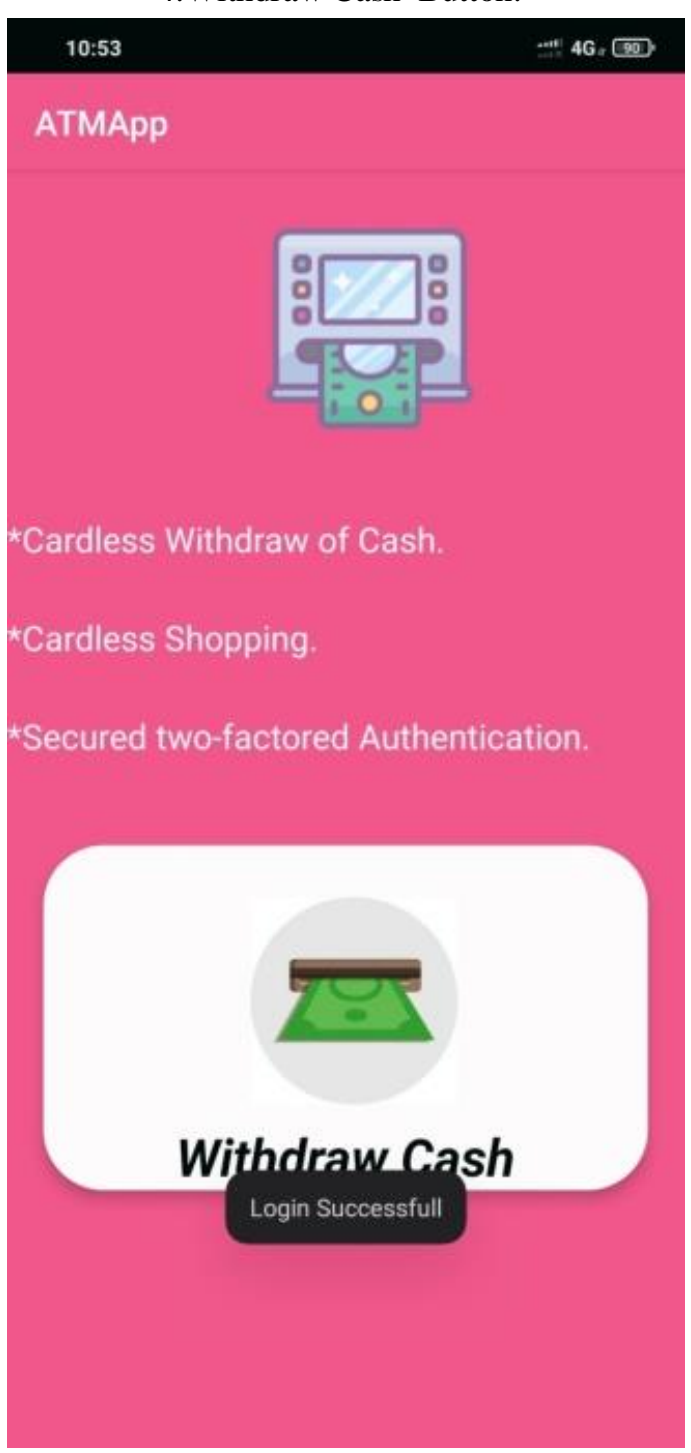

Figure 4:Withdraw Cash

Figure 3: Login

After regisration of account for further process , customer have to login with the same account .
For money withdrawal customer have to press WITHDRAW CASH button. 
International Journal of Engineering Applied Sciences and Technology, 2021

Vol. 6, Issue 3, ISSN No. 2455-2143, Pages 132-140

Published Online July 2021 in IJEAST (http://www.ijeast.com)

6. Create PIN :-

$10: 53 \quad+46, \infty$

5. Enter Amount :-

10:53

-4 - 46.

ATMApp

\section{Details:}

Account:

Saving: 10,000

Delivery Channel:

ATM

Enter Amount:

Enter Amount

NEXT

\section{ATMApp}

\section{Create Pin:}

\section{Cash Pin for Transaction}

\section{Enter Pin here}

*Do not share this pin with anyone.

\section{CONFIRM}

Figure 5:Enter Amount

Customer have to enter the amount he /she wish to withdraw.
Customer have to create PIN for transaction, this PIN will be confedential, customer should'nt share this PIN to anyone for account safety.

7.Verify OTP :- 
International Journal of Engineering Applied Sciences and Technology, 2021

Vol. 6, Issue 3, ISSN No. 2455-2143, Pages 132-140

Published Online July 2021 in IJEAST (http://www.ijeast.com)

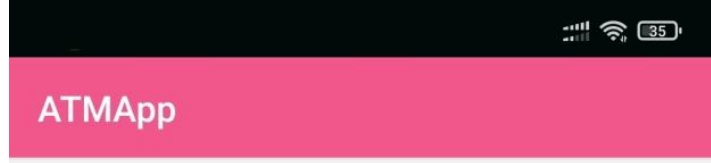

ATM app Verify OTP

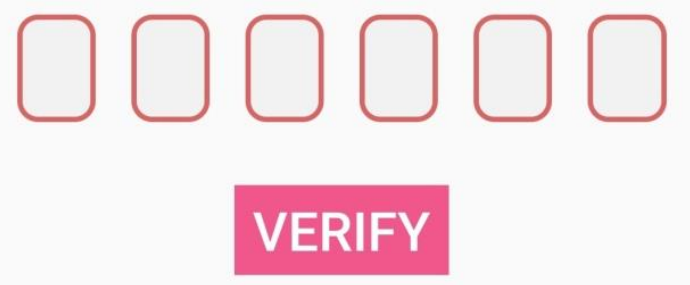

Figure 7 : Verify OTP

ATM app will generate OTP , customer will ente OTP and AATM app will verify that OTP. This will add more safety and security to the transactions.
8. Review :-

$10: 53$

46. ஹ

\section{ATMApp}

\section{Review:}

Account Number:

134987646

Delivery Channel:

ATM

Amount:

amount:

Transaction Pin:

Pin

Figure 8 : Review

This screen is to confirm amount and transaction PIN . 
9. QR Code :-

\section{$10: 54$} ..tin 46 .

\section{ATMApp}

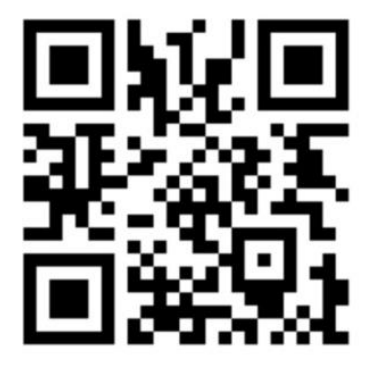

Figure 9 : QR Code

QR code will be generated and will pop up on the screen after confirming the details, then QR code scanner which will be situated in the ATM machine's camera will scan the code.
10. ATM QR code scan: :-

$10: 56 \ldots$
ATMApp

\section{ATM QR code scanner}

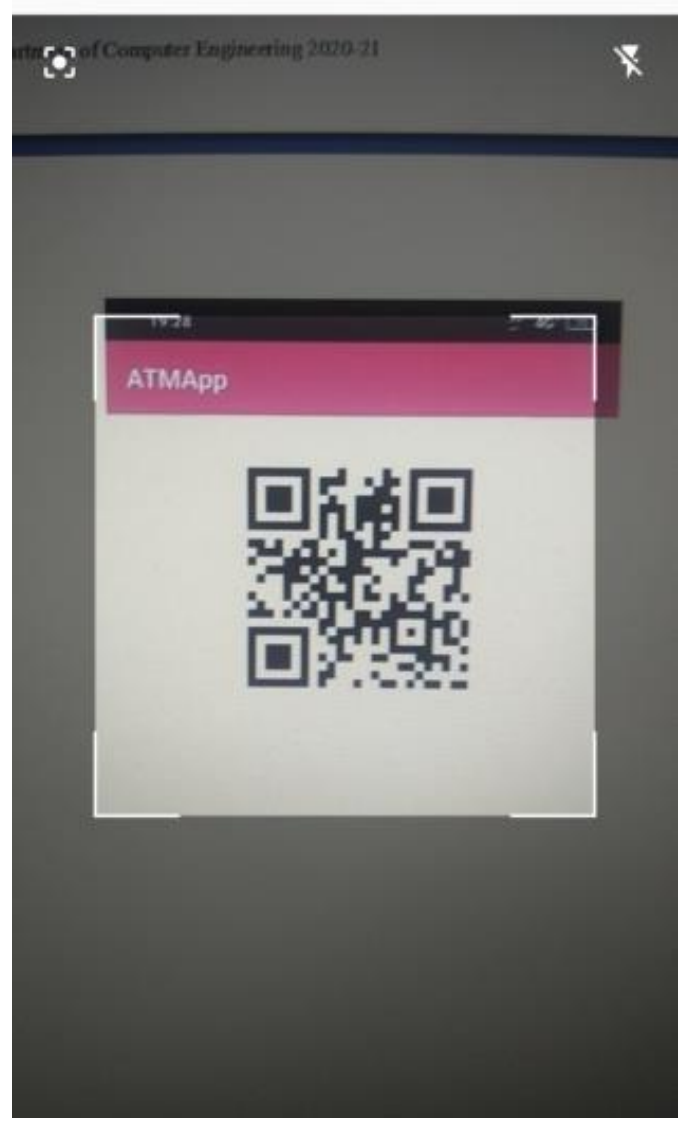

Figure 10 : ATM QR code scanner

This is QR code scanner screen for demonstration, that will scan the QR code from ATM app and after scanning the values of $\mathrm{QR}$ code if the values matched, then only the cash will be despense from the ATM machine.

\section{CONCLUSION}

Time Saving The main purpose of this research is to save customer time to withdrawal cash from ATM machine, by utilizing waiting time in the ATM queue. Normally a successful cash withdrawal transaction takes at least 30 seconds, more in case of wrong attempts; but using this 


\section{International Journal of Engineering Applied Sciences and Technology, 2021 \\ Vol. 6, Issue 3, ISSN No. 2455-2143, Pages 132-140 \\ Published Online July 2021 in IJEAST (http://www.ijeast.com)}

feature, successful transaction will be done only in 10 seconds. That means transaction of cash withdrawal using this feature will take less than half time, so there is more than 50 ATM PIN privacy After using this feature, there is no need to hide ATM PIN on the ATM machine, because customer will not use it on ATM machine. Customer will use QR-code to withdraw cash. Security enhancement Using this feature, PIN security to withdrawal cash is increased. Other than ATM PIN, someone require Mobile banking PIN and QR-code (which is sent on registered Mobile number only) to complete the transaction. Availability of existing system If the ATM machine is free, there is no waiting time; and then we can directly use existing cash withdrawal process. There is no change in system, who don't want to use this feature.

\section{REFERENCE}

[1]Nischal Bansal, Cash withdrawal from ATM machine using Mobile banking, IEEE March 2016, 16143274

[2] L. A Mohammed, Abdul Rahman Ramli, V. Prakash, Mohamad B. Daud, "Smart Card Technology the Internet and Management Vol. (January - April, 20014), pp 12 - 22

[3] Mary Program Knich Vice President, ATM Products, First Data, "Take Your ATM to the Next Level", 30- Aug-2013.

[4] Archana Sharma, Dr. Vineet kansal "Mobile Banking as Technology Adoption and Challengesb(2008)Asian Journal of Communication, 18(4), 318-322.

[5] Key Pousttchi, Martin Schurig “Assessment of Todays Mobile Banking Applications from the View of Customer Requirements" 37th Hawaii International Conference on System Sciences - 2010 .

[6]Uday Hajare, Rajnandini Mahajan, Sulaxan Jadhav,Nishchal Pingale, Sagar Salunke Efficient Cash withdrawal from ATM using mobile banking. Edition Jan 2018 , IRJET.

[7] Junko Yoshida (2002), Smart-card chips advance as market stalls, EE Times, 11 Nov., available online at www.eetimes.com

[8] Daniel, E. 1999. Provision of electronic banking in the UK and the Republic of Ireland. International Journal of Bank Marketing. Vol.17. 